\title{
Persistently HIV-1 seronegative Nairobi sex workers are susceptible to in vitro infection
}

Dorothee Bienzle DVM PhD ${ }^{1}$, Kelly S MacDonald $\mathrm{MD}^{2}$, Karen FT Copeland PhD ${ }^{1}$, Job J Bwayo MD², Francis A Plummer $\mathrm{MD}^{2}$, Kenneth L Rosenthal $\mathrm{PhD}^{1}$

D Bienzle, KS MacDonald, KFT Copeland, JJ Bwayo, FA Plummer, KL Rosenthal. Persistently HIV-1 seronegative Nairobi sex workers are susceptible to in vitro infection. Can J Infect Dis 2000;11(5):259-263.

OBJECTIVE: To evaluate whether resistance to HIV-1 infection in a subset of highly exposed sex workers correlates with resistance at the cellular level.

DESIGN: In vitro evaluation of susceptibility to infection by Kenyan HIV-1 isolates and cellular production of potential mediators of resistance.

SETTING: Samples were collected in a primary care clinic in Nairobi.

PATIENTS: Thirteen individuals from a cohort of sex workers with a similar risk of acquiring HIV infection and six unexposed controls.

INTERVENTIONS: Subjects were provided with appropriate primary care and counselling on the prevention of sexually transmitted diseases.

RESULTS: No inherent cellular resistance to infection was identified. $\mathrm{CD} 8^{+}$cells from a subset of subjects strongly inhibited viral replication.

CONCLUSIONS: Lack of infection in this cohort was not attributable to factors inherent to $\mathrm{CD} 4^{+}$cells. Resistance to HIV infection is likely to be multifactorial, and products of $\mathrm{CD} 8^{+}$cells and unique features of mucosal sites probably contribute to this state.

Key Words: CD8 cell-mediated suppression; HIV; HIV resistance; Sex workers

Des travailleuses du sexe de Nairobi demeurés VIH-négatifs sont sensibles à l'infection in vitro

OBJECTIF : Vérifier si la résistance à l'infection au VIH chez une sous-population de travailleuses du sexe de Nairobi fortement exposée est en corrélation avec la résistance à l'échelon cellulaire.

MODÈLE : Évaluation in vitro de la sensibilité à l'infection par des isolats de VIH-I kényans et production cellulaire de modulateurs potentiels de la résistance.

CONTEXTE : Des échantillons ont été prélevés dans une clinique ambulatoire de Nairobi.

PATIENTS : Treize personnes d'une cohorte de travailleuses du sexe exposés au même risque de contamination par le VIH et six témoins non exposés.

INTERVENTIONS : Les sujets ont reçu le counselling approprié sur la prévention des maladies transmissibles sexuellement et sur les soins de base.

RÉSULTATS : Aucune résistance cellulaire inhérente contre l'infection n'a été identifiée. Les cellules CD8 ${ }^{+}$d'une soussérie de sujets ont fortement inhibé la réplication virale.

CONCLUSIONS : L'absence d'infection dans cette cohorte n'a pas été jugée attribuable à des facteurs propres aux cellules $\mathrm{CD} 4^{+}$. La résistance contre l'infection est probablement plurifactorielle et les produits des $\mathrm{CD} 8^{+}$et des caractéristiques uniques des sites muqueux contribuent probablement à ce phénomène.

\footnotetext{
${ }^{1}$ Department of Pathology and Molecular Medicine, McMaster University, Health Sciences Centre, Hamilton, Ontario; ${ }^{2}$ Department of Medical Microbiology, University of Nairobi, Nairobi, Kenya

Correspondence: Dr D Bienzle, Department of Pathobiology, University of Guelph, Guelph, Ontario N1G 2W1. Telephone 519-824-4120 ext 4351, fax 519-824-5930,e-mail dbienzle@uoguelph.ca 
$S^{-}$ everal studies have reported on individuals that remain persistently seronegative despite repeated exposure to the HIV type 1 (HIV-1). These have included health care workers with accidental exposure (1), infants born to infected mothers (2-4), needle-sharing intravenous drug users (5), individuals engaged in unprotected sexual intercourse $(6,7)$ and prostitutes $(8,9)$. The risk for infection among these cohorts varied greatly, and T cell-mediated immunity, as measured by interleukin (IL)-2 production, lymphocyte proliferation in response to HIV-derived peptides or HIV-specific cytotoxic T lymphocytes, was thought to contribute to resistance in these cases $(1-4,6,7,9,10)$. The proposed mechanism involved priming of $\mathrm{T}$ cell responses with low antigenic doses, and generation of cytokine-mediated $\mathrm{T}$ helper cell type 1 (Th1) immune responses, which upregulate cellular effector functions and downregulate $\mathrm{T}$ cell help for $\mathrm{B}$ cells $(11,12)$.

The beta-chemokines macrophage inflammatory protein (MIP)-1-alpha, MIP-1-beta and Regulated on Activation, Normal T cell Expressed and Secreted (RANTES) are produced by $\mathrm{CD}^{+}$cells, inhibit viral replication (13) and bind to the main HIV coreceptor CCR5 $(14,15)$. Homozygous mutation of CCR5 imparted marked (15) but incomplete (16-18) resistance. Inherent cellular resistance was attributed to overproduction of beta-chemokines (19), stimulation of $\mathrm{CD} 3 / \mathrm{CD} 28$ pathways $(20,21)$, and suppression of HIV transcription by overexpression of IL-16 (22) or undefined factors distinct from chemokines (23). Thus, immune, structural and inducible cellular correlates of resistance to infection by HIV were identified. However, many cases of resistance to infection are not accounted for by these factors, and additional means of evading infection despite repeated exposure remain to be discovered.

TABLE 1

Epidemiological similarity between seronegative, high risk study subjects and the larger HIV-resistant sex worker cohort

\begin{tabular}{|c|c|c|c|}
\hline & $\begin{array}{l}\text { Resistant sex } \\
\text { worker cohort } \\
\quad(n=33)\end{array}$ & $\begin{array}{l}\text { Study subjects } \\
\qquad(n=13)\end{array}$ & $\mathbf{P}$ \\
\hline $\begin{array}{l}\text { Age at cohort entry } \\
\text { (years) }\end{array}$ & $31.8 \pm 5.0$ & $33.7 \pm 5.8$ & 0.38 \\
\hline $\begin{array}{l}\text { Sex partners/day } \\
\text { (mean) }\end{array}$ & $4.2 \pm 1.9$ & $6.6 \pm 2.3$ & 0.004 \\
\hline $\begin{array}{l}\text { Duration of prostitution } \\
\text { at cohort entry } \\
\text { (years) }\end{array}$ & $4.1 \pm 4.5$ & $6.6 \pm 10.8$ & 0.39 \\
\hline $\begin{array}{l}\text { Duration of follow-up } \\
\text { (years) }\end{array}$ & $4.9 \pm 1.7$ & $5.5 \pm 1.4$ & 0.36 \\
\hline $\begin{array}{l}\text { Episodes of gonorrhea } \\
\text { (mean) }\end{array}$ & $0.26 \pm 0.20$ & $0.19 \pm 0.2$ & 0.40 \\
\hline $\begin{array}{l}\text { Episodes of chlamydia } \\
\text { infection (mean) }\end{array}$ & $0.04 \pm 0.06$ & $0.03 \pm 0.05$ & 0.89 \\
\hline $\begin{array}{l}\text { Episodes of genital } \\
\text { ulcers (mean) }\end{array}$ & $0.06 \pm 0.10$ & $0.08 \pm 0.07$ & 0.65 \\
\hline $\begin{array}{l}\text { Condom use (mean } \\
\text { semiquantitative } \\
\text { score) }\end{array}$ & $2.5 \pm 0.8$ & $3.5 \pm 0.4$ & 0.003 \\
\hline
\end{tabular}

Unless otherwise noted, values expressed as $\pm S D$
In this study, we examined $\mathrm{CD} 4^{+}$lymphocyte susceptibility to infection in a group of highly HIV-exposed sex workers from Nairobi, Kenya. The subjects had a significantly increased risk of seroconverting but remained uninfected (8). Resistance to infection in the cohort could neither be accounted for by in vitro resistance nor by overproduction of chemokines. Factors produced by $\mathrm{CD} 8^{+}$cells from some individuals effectively reduced HIV replication.

\section{MATERIALS AND METHODS}

Study subjects: Thirteen cellular samples from the Nairobi sex worker cohort, who were persistently seronegative and remained seronegative after three or more years of follow-up, were available for study. Risk factors for HIV-1 seroconversion in this cohort have been studied since 1985 (8). The risk of infection in the cohort has increased steadily over time; however, the individuals studied remained uninfected as evaluated by serology, immunoblot and polymerase chain reaction (PCR) amplification of $e n v$, nef and $v i f$ sequences, as described in detail previously (8). The subjects were comparable with the larger resistant sex worker cohort from Nairobi in terms of age, sexual practices and concurrent sexually transmitted diseases (Table 1). Samples from infected members of the larger cohort were available for virus isolation, and control samples were obtained from local and North American unexposed individuals. Virus isolation, cell preparations and infections: Virus stocks were produced as previously described (23). In brief, $\mathrm{CD}^{+}$cell-depleted peripheral blood mononuclear cells (PBMCs) from patients were cultured with donor HIV-negative $\mathrm{CD} 4^{+}$ phytohemagglutinin blasts, and the supernatant was tested biweekly for p24 concentration (Organon Teknika, USA). Two Kenyan nonsyncytium-inducing (NSI) HIV strains and one syncytium-inducing (SI) HIV strain were isolated. $\mathrm{CD}^{+}$and $\mathrm{CD}^{-}$ cell fractions, or $\mathrm{CD}^{+}$fractions were immunomagnetically isolated (MiniMACS, Miltenyi Biotec, USA) and exposed to a standardized infection with $10 \mathrm{ng}$ of p24 (corresponding to approximately 500 median tissue culture infective dose [24]) from the respective primary isolate per $10^{6} \mathrm{CD}^{+}$phytohemagglutinin blasts. Additionally, $\mathrm{CD} 4^{+}$cells from four subjects and six controls were each infected with $1 \mathrm{ng}$ and $0.1 \mathrm{ng}$ of $\mathrm{p} 24$. Concentrations of p24 and chemokines (R\&D Systems, Minneapolis, Minnesota) in supernatants of uninfected and infected cultures were determined in triplicate biweekly. After three weeks, the remaining cellular fractions were collected and the genomic DNA was extracted.

CD8 ${ }^{+}$cell inhibition studies: To assess cellular suppression of viral replication, $\mathrm{CD} 8^{+}$cells were added to autologous $\mathrm{CD} 4^{+}$ cells in a 1 to 4 ratio immediately after infection. The supernatants were replenished biweekly, and p24 levels in uninfected cell cultures, infected $\mathrm{CD} 4^{+}$cell cultures and $\mathrm{CD} 4^{+}-\mathrm{CD} 8^{+}$ cocultures were determined biweekly.

CCR5 genotyping: High molecular weight DNA was subjected to PCR amplification with primers spanning the described 32 base pair deletion in the gene coding for CCR5 (16). The amplicons were separated in 3\% agarose gels.

Statistical analysis: Differences between the control infections and the sample population were evaluated with the Wilcoxon 
TABLE 2

Viral p24 concentrations in $\mathrm{CD}^{+}$culture supernatants from persistently seronegative and control individuals in vitro infected with primary HIV isolates

\begin{tabular}{|c|c|c|c|c|c|c|c|c|c|}
\hline & \multirow{2}{*}{$\begin{array}{l}\text { Inoculum } \\
\text { (ng) }\end{array}$} & \multicolumn{4}{|c|}{ p24 concentration $(\mathrm{pg} / \mathrm{mL})$ - Day 7} & \multicolumn{4}{|c|}{ p24 concentration $(\mathrm{pg} / \mathrm{mL})$ - Day 14} \\
\hline & & $\bar{x}$ & SD & $\bar{x}$ & SD & $\bar{x}$ & SD & $\bar{x}$ & SD \\
\hline \multirow[t]{2}{*}{$\mathrm{NSI}-1$} & & \multicolumn{2}{|c|}{ Subjects $(n=9)$} & \multicolumn{2}{|c|}{ Controls $(n=6)$} & \multicolumn{2}{|c|}{ Subjects $\quad(n=9)$} & \multicolumn{2}{|c|}{ Controls $(n=6)$} \\
\hline & 10 & 1151 & 242 & 1829 & 198 & 2315 & 309 & 2431 & 222 \\
\hline \multirow[t]{4}{*}{ NSI-2 } & & Sub & $(n=4)$ & Con & $=6)$ & \multicolumn{2}{|c|}{ Subjects $(n=4)$} & \multicolumn{2}{|c|}{ Controls $(n=6)$} \\
\hline & 10 & 15,875 & 2750 & 19,354 & 3335 & 20,093 & 3124 & 24,654 & 3917 \\
\hline & 1 & 7441 & 884 & 8098 & 1231 & 17,049 & 2323 & 17,814 & 2534 \\
\hline & 0.1 & 2398 & 450 & 2412 & 690 & 10,005 & 1438 & 9465 & 1982 \\
\hline \multirow[t]{2}{*}{ SI } & & Sub & $(n=13)$ & \multicolumn{2}{|c|}{ Controls $(n=6)$} & \multicolumn{2}{|c|}{ Subjects $\quad(n=13)$} & \multicolumn{2}{|c|}{ Controls $(n=6)$} \\
\hline & 10 & 21,627 & 8224 & 23,252 & 8482 & 30,982 & 5908 & 33,293 & 6189 \\
\hline
\end{tabular}

NSI Nonsyncytium-inducing HIV; SI Syncytium-inducing HIV

signed-rank test for nonparametric samples (25). Inhibitions of viral replication were compared using the paired $t$-test (25).

\section{RESULTS}

Susceptibility of $\mathrm{CD} 4^{+}$cells from resistant subjects to in vitro infection: Two NSI isolates and one strongly SI virus were isolated. Purified $\mathrm{CD}^{+}{ }^{+}$cells from 13 members of the resistant cohort, and one local and five Caucasian control individuals were infected with the primary isolates. Although the individual viruses differed in their replicative ability, no significant differences were observed between the sample population and controls with either of the NSI viruses, dilutions of an NSI virus or with the SI virus (Table 2). Similar results were obtained in four subjects with clade B North American primary viral isolates (data not shown).

Beta-chemokine production by $\mathrm{CD}^{+}$cells: To determine whether beta-chemokine production is associated with reduced or enhanced infectivity of $\mathrm{CD} 4^{+}$cells, the concentrations of MIP-1-alpha, MIP-1-beta and RANTES were determined. No significant differences between infected and uninfected cultures were noted. Rather, chemokine production was characteristic for each individual, regardless of whether the cells were infected (Figure 1).

$\mathrm{CD}^{+}$cell-mediated viral suppression: To assess the effect of $\mathrm{CD}^{+}$cells on virus replication, autologous, unstimulated $\mathrm{CD} 8^{+}$ cells were added to $\mathrm{CD} 4^{+}$cells immediately following infection. In four individuals, profound inhibition $(\bar{x}=93.4 \%)$ of NSI viruses was observed. There was little reduction $(\bar{x}=2.7 \%)$ of SI virus replication. $\mathrm{CD}^{+}$cells from unexposed individuals suppressed replication of NSI viruses $(\overline{\times}=90.1 \%)$ and SI viruses $(\bar{x}=62.3 \%)$. Thus, in some members of this cohort, $\mathrm{CD}^{+}$cells specifically suppressed NSI viral isolates.

CCR5 genotyping: No deletions in the amplified segment of CCR5 were identified in the seronegative or seropositive subjects (data not shown).

\section{DISCUSSION}

In this study, the susceptibility of $\mathrm{CD} 4^{+}$cells from a group of persistently HIV-seronegative, commercial sex workers from Nairobi, Kenya, was investigated (8). The odds ratio for sero-

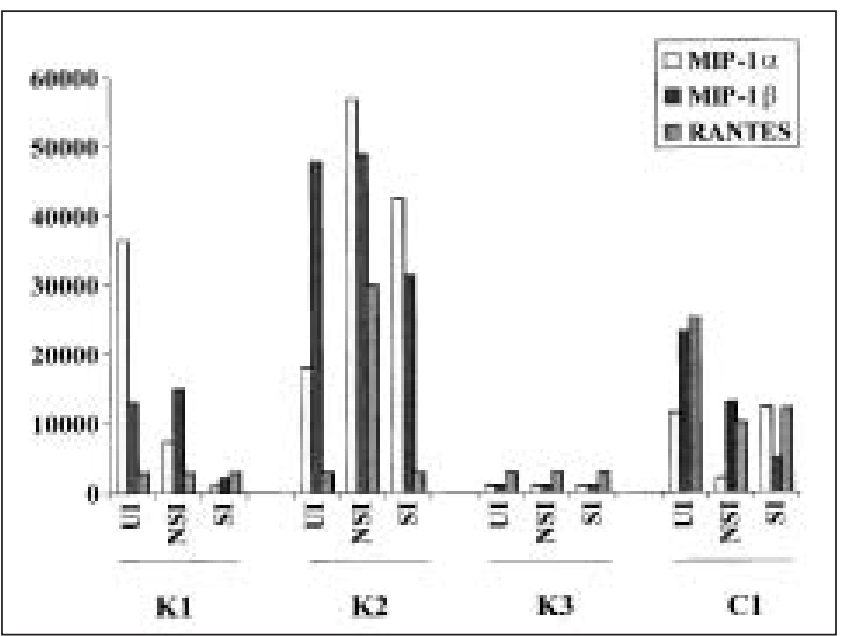

Figure 1) Beta-chemokine production by $\mathrm{CD}^{+}$lymphocytes varies between individuals, independent of infection. $C D 4^{+}$cells were uninfected (UI), infected with syncytium-inducing (SI) or nonsyncytium-inducing (NSI) viruses, and the concentration of macrophage inflammatory protein (MIP)-1-alpha (MIP-1 $\alpha$ ), MIP-1-beta (MIP-1 $\beta$ ) and RANTES in supernatants was determined by immunoassay

conversion for all participants in the study increased with the duration of prostitution, and the probability of remaining seronegative decreased exponentially over time (8). However, in the subgroup reported on by Fowke et al (8), a protective effect that increased with the duration of prostitution was observed. This is a very unusual situation, and because these individuals present a unique opportunity to study apparent natural resistance to HIV infection, we sought to evaluate in vitro correlates of infectivity or resistance.

Samples from 13 randomly selected individuals were available for study; they did not vary from other 'resistant' members of the cohort significantly with respect to age, duration of prostitution or sexually transmitted diseases (Table 1). The subset had a greater number of sex partners per day and concomitantly higher condom use. Neither of these factors was expected to influence cellular characteristics pertinent to this study. In vitro studies revealed no constitutive barriers to HIV 
infection or replication. These findings exclude the presence of a structural defect such as an altered receptor or coreceptor for the virus, and suggest that $\mathrm{CD} 4^{+}$cells from the subjects were inherently susceptible to infection and competent to allow for viral replication. No difference regarding the syncytial phenotype was observed, indicating that the change in cell tropism that is commonly associated with a switch from NSI to SI phenotype may proceed unimpaired in the cohort.

Production of chemokines by $\mathrm{CD}^{+}$cells was not associated with resistance to infection by NSI and SI viruses in this study. MIP-1 and MIP-1 production exceeded $40,000 \mathrm{pg} / \mathrm{mL}$ in only one subject, and this was independent of infection. There was much individual variation in chemokine production, similar to what has been described for CCR5 expression (26). In other studies, excessive production of the chemokines MIP-1-alpha, MIP-1-beta and RANTES (30,000 to $100,000 \mathrm{pg} / \mathrm{mL}$ ) correlated with a reduction or absence of $\mathrm{CD}^{+}$cell infection, and addition of $200,000 \mathrm{pg} / \mathrm{mL}$ of all three chemokines was required to block viral replication in $\mathrm{CD}^{+}$cells $(20,27)$. Thus, competition for binding to CCR5 appears to require very high amounts of all three chemokines in combination, and autologous production at levels exceeding those observed in this study may be necessary for a protective effect. These findings do not preclude protection specifically mediated at mucosal sites by nonlymphoid production of chemokines or other factors. Interestingly, synthesis of the above chemokines has been associated with a Th1 immune response induced by a bacterial antigen (28). Th1 immune responses correlated with relative protection from HIV infection and from disease progression, while in the later stages of HIV disease, cellular defects became more pronounced and antibody production persisted, characteristic of Th2 immune responses $(12,29)$. The subjects in the present study were exposed to numerous other sexually transmitted organisms (30). Therefore, it is conceivable that induction of a Th1 immune response and local secretion of chemokines could impair the establishment of HIV infection at the mucosal site.

Concurring with previous reports that the CCR 532 phenotype is unique to individuals of Caucasian descent (31), nei-

\section{REFERENCES}

1. Pinto LA, Sullivan J, Berzofsky JA, et al. ENV-specific cytotoxic T lymphocyte responses in HIV seronegative health care workers occupationally exposed to HIV-contaminated body fluids. J Clin Invest 1995;96:867-76.

2. Rowland-Jones SL, Nixon DF, Aldhous MC, et al. HIV-specific cytotoxic T-cell activity in an HIV-exposed but uninfected infant. Lancet 1993;341:860-1.

3. de Maria A, Cirillo C, Moretta L. Occurrence of human immunodeficiency virus type I (HIV-1)-specific cytolytic T cell activity in apparently uninfected children born to HIV-1-infected mothers. J Infect Dis 1994;170:1296-9.

4. Cheynier R, Langlade-Demoyen P, Marescot MR, et al. Cytotoxic $\mathrm{T}$ lymphocyte responses in the peripheral blood of children born to human immunodeficiency virus-1-infected mothers. Eur J Immunol 1992;22:2211-7.

5. Beretta A, Weiss SH, Rappocciolo G, et al. Human immunodeficiency virus type 1 (HIV-1)-seronegative injection drug users at risk for HIV exposure have antibodies to HLA class I antigens and T cells specific for HIV envelope. J Infect Dis 1996;173:472-6.

6. Clerici M, Giorgi JV, Chou CC, et al. Cell-mediated immune ther resistance to infectability with viruses binding to CCR5 nor the described 32 base pair deletion in CCR 5 were identified in subjects in the present study. Kenyan viral isolates belong predominantly to clade $\mathrm{A}$ and a smaller proportion to clade $\mathrm{D}$ (32), but HIV-1 subtypes A, B, C, D and E and group O viruses all rely on CCR5 for viral entry and do not replicate in cells from CCR5 32 homozygous individuals (33). Thus, resistance in this cohort was not due to properties of $\mathrm{CD} 4^{+}$cells.

Noncytolytic $\mathrm{CD}^{+}$cell suppression of viral replication has been described in long term nonprogressing patients (34), and correlated with CD4 count and a lack of disease progression $(35,36)$. Although high levels of the beta-chemokines inhibit infection by NSI isolates (14), discussion continues regarding the complete identity of the $\mathrm{CD}^{+}$cell-derived factors (37). The suppressive effect observed by coculture with $\mathrm{CD} 8^{+}$cells in this study was specific to NSI isolates and, therefore, may have been partially mediated by $\mathrm{CD}^{+}$cell production of chemokines. However, only one CD8 cell per four CD4 cells was present, and the $\mathrm{CD} 8^{+}$cells were not previously stimulated in vitro, suggesting that very high constitutive production of chemokines is required. Thus, it is likely that factors other than those described in this study contribute to in vitro and in vivo resistance.

The contribution of cytolytic immune responses to HIV resistance in this cohort of persistently seronegative individuals was not assessed; instead, $\mathrm{CD}^{+}$cell nonlytic effector functions were evaluated. Previous studies have identified cytolytic $\mathrm{T}$ cell reactivity in a small percentage of exposed sex workers from Gambia (9), and in members of the cohort reported on here (10). Thus, resistance to infection may be due to several factors, including cytolytic and suppressive functions of $\mathrm{CD}^{+}$cells. Because there was no inherent interference with infection of isolated $\mathrm{CD} 4^{+}$cells, there are likely to be factors modulating or preventing infection at the mucosal site of initial exposure. $\mathrm{CD}^{+}$cells may exert their most profound effect by limiting an infection to a degree sufficient for generating major histocompatibility complex class I-restricted cytotoxic $\mathrm{T}$ lymphocytes, which are then able to eliminate virally infected cells at a localized site. response to human immunodeficiency virus (HIV) type 1 in seronegative homosexual men with recent sexual exposure to HIV-1. J Infect Dis 1992;165:1012-9.

7. Langlade-Demoyen P, Ngo-Giang-Huong N, Ferchal F, Oksenhendler E. Human immunodeficiency virus (HIV) nefspecific cytotoxic $\mathrm{T}$ lymphocytes in noninfected heterosexual contact of HIV-infected patients. J Clin Invest 1994;93:1293-7.

8. Fowke KR, Nagelkerke NJ, Kimani J, et al. Resistance to HIV-1 infection among persistently seronegative prostitutes in Nairobi, Kenya. Lancet 1996;348:1347-51.

9. Rowland-Jones S, Sutton J, Ariyoshi K, et al. HIV-specific cytotoxic T-cells in HIV-exposed but uninfected Gambian women. Nat Med 1995;1:59-64.

10. Rowland-Jones SL, Doug T, Fowke KR, et al. Cytotoxic T cell responses to multiple conserved HIV epitopes in HIV-resistant prostitutes in Nairobi. J Clin Invest 1998;102:1758-65.

11. Shearer GM, Clerici M. Protective immunity against HIV infection: has nature done the experiment for us? Immunol Today 1996;17:21-4.

12. Clerici M, Berzofsky JA, Shearer GM, Tacket CO. Exposure to human immunodeficiency virus (HIV) type I indicated by HIV- 
specific $\mathrm{T}$ helper cell responses before detection of infection by polymerase chain reaction and serum antibodies. J Infect Dis 1991;164:178-82.

13. Walker CM, Moody DJ, Stites DP, Levy JA. CD8+ lymphocytes can control HIV infection in vitro by suppressing virus replication. Science 1986;234:1563-6.

14. Cocchi F, DeVico AL, Garzino-Demo A, Arya SK, Gallo RC, Lusso P. Identification of RANTES, MIP-1 , and MIP-1 as the major HIVsuppressive factors produced by CD8 + T cells. Science 1995;270:1811-5.

15. Liu R, Paxton WA, Choe S, et al. Homozygous defect in HIV-1 coreceptor accounts for resistance of some multiplyexposed individuals to HIV-1 infection. Cell 1996;86:367-77.

16. Biti R, French R, Young J, Bennetts B, Stewart G, Liang T. HIV1 infection in an individual homozygous for the CCR5 deletion allele. Nat Med 1997;3:252-3.

17. O'Brien TR, Winkler C, Dean M, et al. HIV-1 infection in a man homozygous for CCR . Lancet 1997;349:1219.

18. Theodorou I, Meyer L, Magierowska M, Katlama C, Rouzioux C, and the Seroco Study Group. HIV-1 infection in an individual homozygous for CCR5 32. Lancet 1997;349:1219-20.

19. Paxton WA, Martin SR, Tse D, et al. Relative resistance to HIV-1 infection of CD4 lymphocytes from persons who remain uninfected despite multiple high-risk sexual exposure. Nat Med 1996;2:412-7.

20. Carroll RG, Riley JL, Levine BL, et al. Differential regulation of HIV-1 fusion cofactor expression by $\mathrm{CD} 28$ costimulation of $\mathrm{CD} 4+$ T cells. Science 1997;276:273-6.

21. Riley JL, Carroll RG, Levine BL, et al. Intrinsic resistance to $\mathrm{T}$ cell infection with HIV type 1 induced by $\mathrm{CD} 28$ costimulation. J Immunol 1997; 158:5545-53.

22. Zhou P, Goldstein S, Devadas K, Tewari D, Notkins AL. Human CD4 + cells transfected with IL-16 cDNA are resistant to HIV-1 infection: inhibition of mRNA expression. Nat Med 1997;3:659-64.

23. Copeland KF, Leith JG, McKay PJ, Rosenthal KL. CD8+ T cell supernatants of HIV type 1 -infected individuals have opposite effects on long terminal repeat-mediated transcription in T cells and monocytes. AIDS Res Hum Retroviruses 1997;13:71-7.

24. Dulbeeco, R. End-point method-measurement of the infectious titer of a viral sample. In: R Dulbecco, HS Ginsberg, eds. Virology, 2nd edn. Philadelphia: JB Lippinscott, 1980:325-7.

25. Glantz SA. Primer of Biostatistics. New York: McGraw Hill, 1997:282-322

26. Bleul CC, Wu L, Hoxie JA, Springer TA, Mackay CR. The HIV coreceptors CXCR4 and CCR5 are differentially expressed and regulated on human T lymphocytes. Proc Natl Acad Sci USA 1997;94:1925-30.

27. Simmons G, Wilkinson D, Reeves JD, et al. Primary, syncytiuminducing human immunodeficiency virus type 1 isolates are dual-tropic and most can use either Lestr or CCR5 as coreceptors for virus entry. J Virol 1996;70:8355-60.

28. Schrum S, Probst P, Fleischer B, Zipfel PF. Synthesis of the ccchemokines MIP-1-alpha, MIP-1-beta, and RANTES is associated with a type 1 immune response. J Immunol 1996;157:3598-604.

29. Clerici M, Shearer GM. The Th1-Th2 hypothesis of HIV infection: new insights. Immunol Today 1994;15:575-81.

30. Plummer FA, Simonsen JN, Cameron DW, et al. Cofactors in male-female sexual transmission of human immunodeficiency virus type 1 . J Infect Dis 1991;163:233-9.

31. Dean M, Carrington M, Winkler C, et al. Genetic restriction of HIV-1 infection and progression to AIDS by a deletion allele of the CKR5 structural gene. Science 1996;273:1856-62.

32. Poss M, Gosink J, Thomas E, et al. Phylogenetic evaluation of Kenyan HIV type 1 isolates. AIDS Res Hum Retroviruses 1997;13:493-9.

33. Zhang L, Huang Y, He T, Cao Y, Ho DD. HIV-1 subtype and second-receptor use. Nature 1996;383:768.

34. Cao Y, Qin L, Zhang L, Safrit J, Ho DD. Virologic and immunologic characterization of long-term survivors of human immunodeficiency virus type 1 infection. $\mathrm{N}$ Engl J Med 1995;332:201-8.

35. Gomez AM, Smaill FM, Rosenthal KL. Inhibition of HIV replication by $\mathrm{CD} 8+\mathrm{T}$ cells correlates with $\mathrm{CD} 4$ counts and clinical stage of disease. Clin Exp Immunol 1994;97:68-75.

36. Mackewicz CE, Ortega HW, Levy JA. CD8+ cell anti-HIV activity correlates with the clinical state of the infected individual. J Clin Invest 1991;87:1462-6.

37. Mackewicz CE, Barker E, Levy JA. Role of the beta-chemokines in suppressing HIV replication. Science 1996;274:1393-5. 


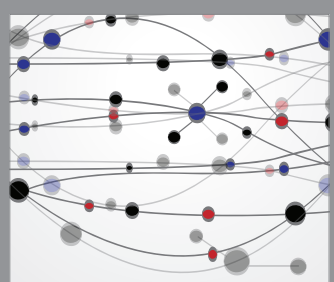

The Scientific World Journal
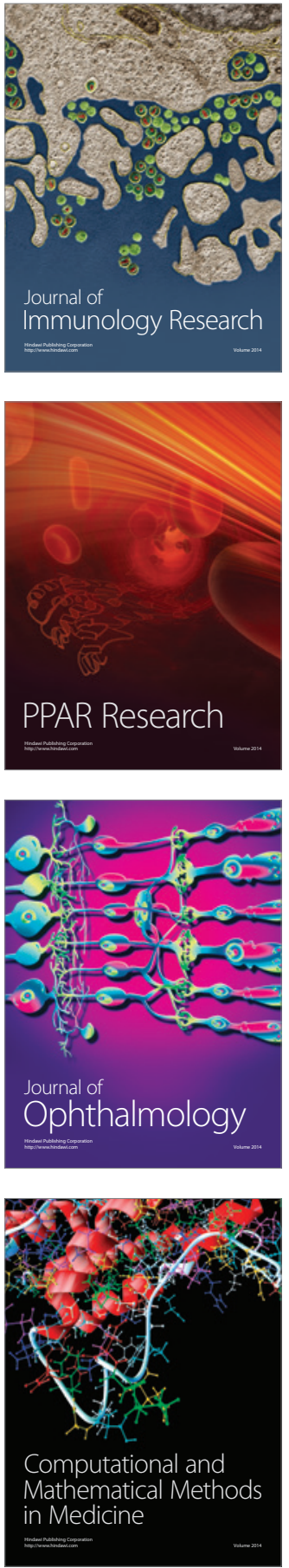

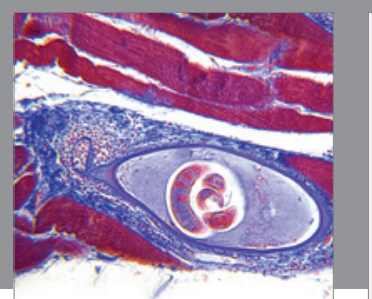

Gastroenterology Research and Practice

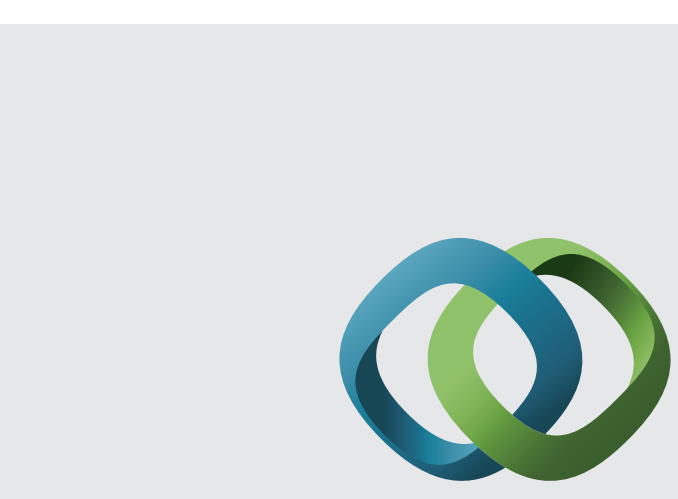

\section{Hindawi}

Submit your manuscripts at

http://www.hindawi.com
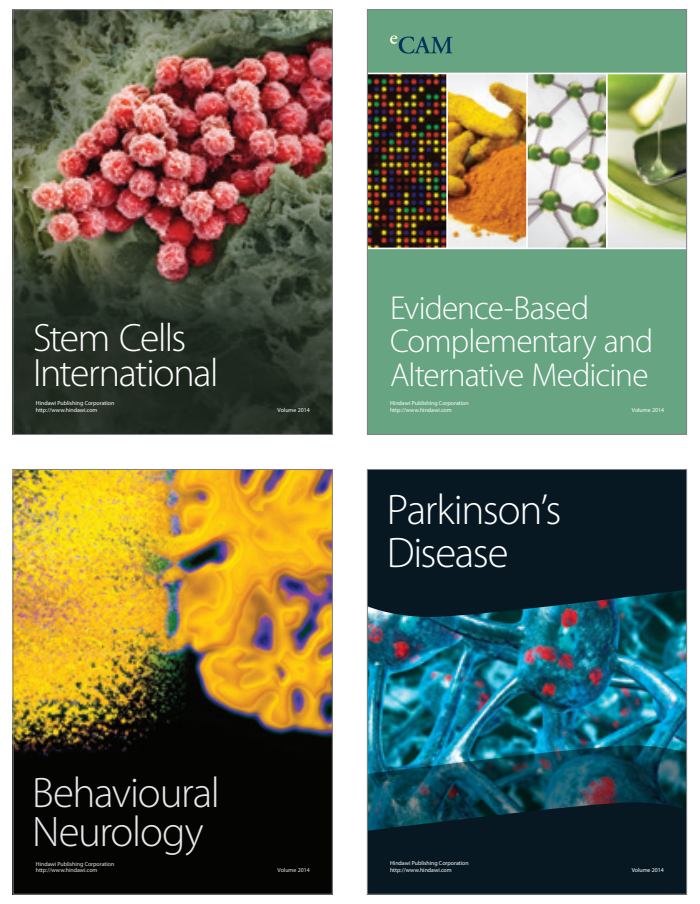
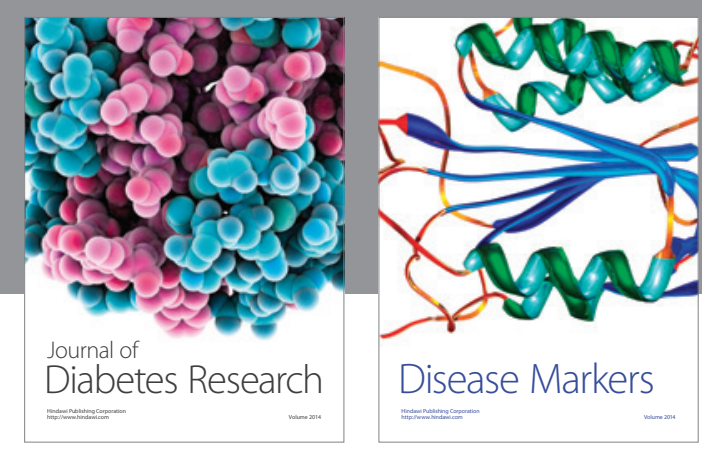

Disease Markers
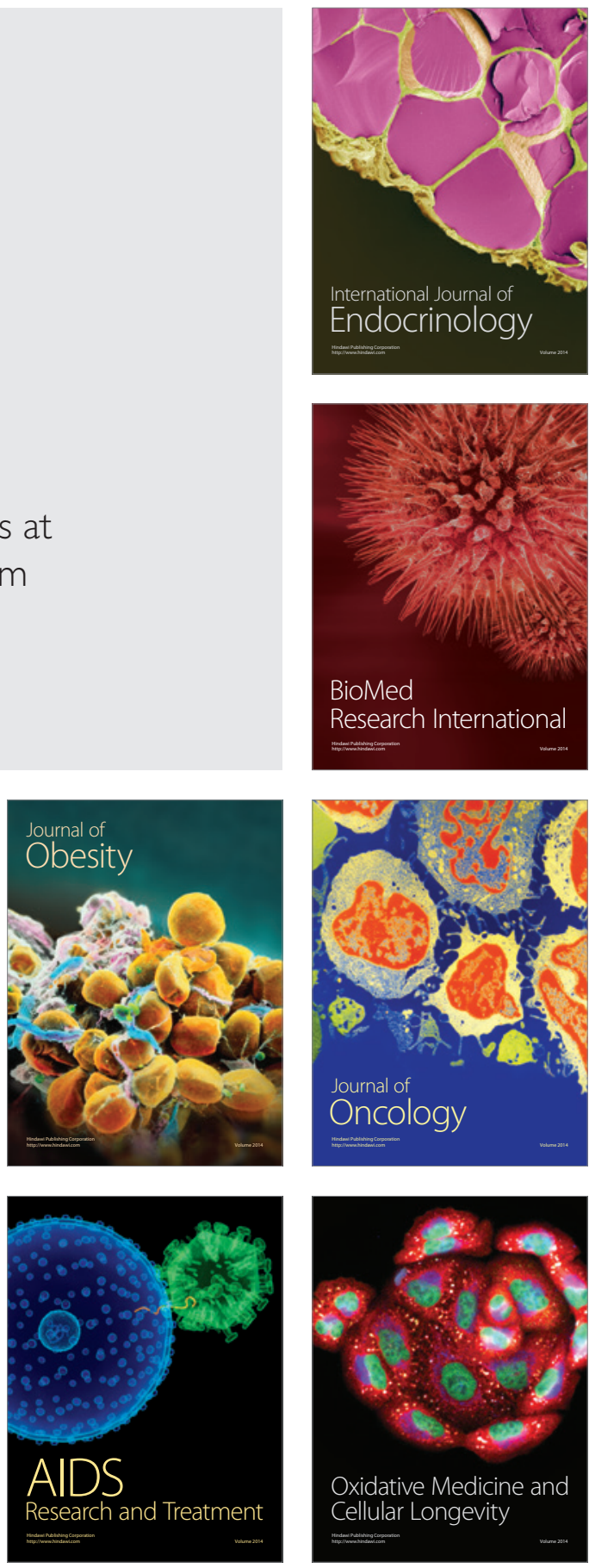